\title{
Evidence for a polysaccharide-binding domain in Hormoconis resinae glucoamylase P: effects of its proteolytic removal on substrate specificity and inhibition by $\beta$-cyclodextrin
}

\author{
Richard Fagerström
}

Tel: + 3580 1332892. Fax: + 35801333346.

Research Laboratories Alko Ltd, POB 350, SF-00101 Helsinki, Finland
The hydrolysis of soluble starch, raw starch and pullulan with recombinant glucoamylase $P$ from Hormoconis resinae was competitively inhibited by $\beta$ cyclodextrin with apparent $K_{i}$ values of $190 \mu \mathrm{M}, 13 \mu \mathrm{M}$ and 1.4 $\mu \mathrm{M}$, respectively. Inhibition of dextran hydrolysis was partial: a maximum inhibition of $22 \%$ was achieved with a dextran concentration of $0.3 \times K_{\mathrm{m}}$ and up to $4 \mathrm{mM}$ $\beta$-cyclodextrin. Hydrolysis of short oligosaccharides was not inhibited by $\beta$-cyclodextrin at levels up to $20 \mathrm{mM}$. The enzyme bound to raw starch at $\mathrm{pH} 4.3$ and $4{ }^{\circ} \mathrm{C}$ with an association constant of $3.4 \times 10^{5} \mathrm{M}^{-1}$. Sequence alignment studies showed raw-starch-binding consensus amino acids in the C-terminal part of glucoamylase P. Partial hydrolysis with papain resulted in degradation of deglycosylated glucoamylase $P$ into three fragments of 53,51 and $14 \mathrm{kDa}$, respectively, as estimated by SDS-PAGE. The amino-terminal sequences of the 51 and $53 \mathrm{kDa}$ fragments were identical with that of native glucoamylase $P$. The amino terminus of the $14 \mathrm{kDa}$ fragment (Ser-Ser-X-GIn-Val-Ser-), corresponded to the sequence starting at residue 474 of intact glucoamylase $P$. Kinetic measurements of truncated glucoamylase $P$ showed changes in the $K_{m}$ values of larger polysaccharides, but no changes in $k_{\text {cat }}$ values compared to the intact enzyme. It was concluded that glucoamylase $P$ contains a catalytic core domain and a raw-starch-binding domain involved in inhibition of polysaccharide hydrolysis by $\beta$-cyclodextrin.

Keywords: glucoamylase P, Hormoconis resinae, polysaccharide-binding domain, starch digestion, enzyme-substrate interaction

\section{INTRODUCTION}

The binding and hydrolysis of raw starch by glucoamylases $(1,4-\alpha$-D-glucan glucohydrolase, EC 3.2.1.3) have been previously studied in detail with Aspergillus (Dalmia \& Nikolov, 1991; Medda et al., 1982), Rhizopus (Takahashi et al., 1985) and Endomycopsis fibuligera (Ueda \& Saha, 1983). The results have suggested a structural organization of the polypeptides into core (catalytic) and tail (raw-starch-binding) domains (Svensson et al., 1986), as has also been proposed for cellulases (van Tilbeurgh $e t$ al., 1986).

The raw-starch-binding domain of Rhizopus glucoamylase

Abbreviations: DP, degree of polymerization; glucoamylase $\mathrm{P}_{c}$ ' 'core' fragment of glucoamylase $P$; glucoamylase $P_{t}$ ' 'tail' fragment. has been found to be located in the $\mathrm{N}$-terminus (Takahashi et al., 1985) and that of Aspergillus glucoamylase in the Cterminal part of the polypeptide (Svensson et al., 1986). The absence of this domain in one form of native $A$. niger glucoamylase (G2) does not seem to change its kinetic properties towards smaller oligosaccharides compared to the other native form (G1) containing this domain (Meagher et al., 1989). The same results have been obtained by deleting this domain from Aspergillus sp. K27 (Abe et al., 1990) and A. niger glucoamylase G1 (Stoffer et al., 1993) by limited proteolysis.

Cyclodextrins have been reported to inhibit many carbohydrate hydrolysing enzymes, such as $\alpha$-amylase (Hayashida et al., 1990; Kobayashi et al., 1988), $\beta$-amylase (Thoma \& Koshland, 1960), pullulanase (Marshall, 1973) and some glucoamylases (Savel'ev et al., 1989; Monma et al., 1989; Fukuda et al., 1992). The binding of $\beta$ - 
cyclodextrin by the isolated raw-starch-binding domain of Aspergillus glucoamylase has also been studied (Belshaw \& Williamson, 1993).

The high debranching (high activity towards 1,6- $\alpha$ slycosidic bonds) glucoamylase P from Hormoconis resinae (McCleary \& Anderson, 1980; Fagerström et al., 1990; Fagerström, 1991) has been cloned and expressed in Trichoderma reesei (Joutsjoki \& Torkkeli, 1992; Joutsjoki et al., 1993). The recombinant glucoamylase $\mathrm{P}$ has been shown to retain the properties of the wild-type enzyme (Fagerström, 1994). The amino acid sequence of this enzyme is similar (47.7\% identity) to that of Aspergillus glucoamylase. The long highly O-glycosylated threonine/serine-rich region (TS region) proposed to separate the raw-starch-binding domain from the catalytic core of Aspergillus glucoamylase G1 seems to be absent in glucoamylase P (Vainio et al., 1993).

None of the glucoamylases, cellulases and other carbohydrate hydrolases shown to contain a separate binding domain have been crystallized intact. Only the core structures have been crystallized (Aleshin et al., 1992; Rouvinen et al., 1990). In the case of cellobiohydrolase II, the structure of the tail part has been obtained by NMR studies (Kraulis et al., 1989). Thus, there is no clear view of whether and how the core and tail interplay during hydrolysis of large carbohydrate substrates.

\section{METHODS}

Enzyme preparation. Recombinant Hormoconis resinae glucoamylase $\mathrm{P}$ was produced in Trichoderma reesei (ALKO2743; Joutsjoki et al., 1993) and purified as described by Fagerström (1994). Fraction GAP-A (molecular mass $70 \mathrm{kDa}$ ) was used in inhibition and corn-starch-binding experiments. In papaindigestion experiments, a deglycosylated sample was used. The deglycosylation was performed by incubating $3 \mathrm{mg}$ glucoamylase $\mathrm{P}$ with $0.2 \mathrm{IU}$ endoglycosidase $\mathrm{F}$ (New England BioLabs) in $20 \mathrm{mM}$ sodium acetate, $\mathrm{pH} 5.5$, containing $1 \mathrm{mM}$ PMSF (Sigma) and $10 \mu \mathrm{g}$ pepstatin A (Sigma) $\mathrm{ml}^{-1}$ for $23 \mathrm{~h}$ at $37^{\circ} \mathrm{C}$. The $\mathrm{pH}$ of this digest was elevated by adding $0 \cdot 1$ vol. $0.5 \mathrm{M}$ potassium phosphate, $\mathrm{pH} 7.5$, before further deglycosylation with $0.4 \mathrm{IU}$ of $\mathrm{N}$-glycosidase $\mathrm{F}$ (New England BioLabs) for $18 \mathrm{~h}$ at $37^{\circ} \mathrm{C}$ after addition of fresh PMSF (to $1 \mathrm{mM}$ ) and pepstatin A (to $10 \mu \mathrm{g} \mathrm{ml}^{-1}$ ). The deglycosylated sample was purified on a Superose 12 (Pharmacia) gel-exclusion column $(1 \times 30 \mathrm{~cm})$ equilibrated with $20 \mathrm{mM}$ sodium acetate buffer. $\mathrm{pH} 5 \cdot 7$, containing $150 \mathrm{mM} \mathrm{NaCl}$ and run at $25 \mathrm{ml} \mathrm{h}^{-1}$. Absorbance at $280 \mathrm{~nm}$ was followed. The concentration of protein was estimated spectrophotometrically at $205 \mathrm{~nm}$ by the method of Scopes (1974) using an $A_{1 \% \mathrm{~m}}^{1 \%}$ value of 307 . All enzyme preparations were stored at $+4^{\circ} \mathrm{C}$ or at $-20^{\circ} \mathrm{C}$ with only one thawing, because some loss in specific activity was observed after repeated freezings and thawings.

Substrates. Zulkowsky starch (Merck) was used as soluble starch and tested for the presence of shorter oligosaccharides by thin-layer chromatography on silica TLC plates (Merck, silica gel 60) as described by Hansen (1975) with the modification introduced by Melasniemi (1987). Corn starch (raw starch,
Merck) was washed three times prior to use with $50 \mathrm{mM}$ sodium acetate buffer, $\mathrm{pH} 4 \cdot 3$. Sedimentation between the washings was by centrifugation for $5 \mathrm{~min}$ at $2800 \mathrm{~g}$. Pullulan (average degree of polymerization, DP, about 1200; Cattlay, 1979) and the series of maltose to maltoheptaose (over $90 \%$ pure) were used as obtained from Sigma. Dextran T-10 (DP about 60) was from Pharmacia. The series of isomaltose to isomaltoheptaose (over $90 \%$ pure) was from Biocarb.

Activity measurements and estimations of kinetic constants. Initial rates were obtained by incubating substrate and enzyme in $50 \mathrm{mM}$ sodium acetate, $\mathrm{pH} 4.3$, containing $150 \mu \mathrm{g}$ ovalbumin $\mathrm{ml}^{-1}$ (Sigma, grade $\mathrm{V}$ ) at $30^{\circ} \mathrm{C}$, as described by Fagerström (1991), unless stated otherwise. Released glucose was measured by using a glucose-dehydrogenase-based assay (Merck, Granulotest 100). One unit of activity is defined as $1 \mu \mathrm{mol}$ glucose released $\mathrm{min}^{-1}$. Incubation times of 0 to $30 \mathrm{~min}$ were used for pullulan, soluble starch, maltotriose to maltoheptaose, and isomaltotriose to isomaltoheptaose. For isomaltose and maltose, incubation times of 0 to $80 \mathrm{~min}$ were used, and in the case of dextran T-10 and corn starch incubations, up to at least $120 \mathrm{~min}$. Inhibition studies with corn starch were performed in $50 \mathrm{mM}$ sodium acetate buffer, $\mathrm{pH} 4 \cdot 3$, omitting ovalbumin from the reaction mixture. Steady-state rates at incubation times between 60 and $180 \mathrm{~min}$ (see, for example, Fig. 3) were used. Preliminary results obtained by shaking (250 r.p.m.) the mixture during incubation showed no difference as compared to samples without shaking. Thus, for convenience, all incubations were performed statically with mixing only before samples were taken. The apparent kinetic constants were estimated by using a computer program based on the method introduced by Cornish-Bowden (1977) to fit the steadystate rate equations. The type of inhibition was estimated from Lineweaver-Burk plots. To obtain apparent $K_{\mathrm{i}}$ values, Dixon plots were used, as well as calculations from the LineweaverBurk plots.

Estimation of the association constant of glucoamylase $\mathbf{P}$ to corn starch. Binding of $3 \cdot 2 \mu \mathrm{M}$ glucoamylase $\mathrm{P}$ to $100 \mathrm{mg}$ corn starch in $1 \mathrm{ml} 50 \mathrm{mM}$ sodium acetate, $\mathrm{pH} 4 \cdot 3$, was followed by incubating the sample under mixing ( 250 r.p.m., horizontal) at $+4{ }^{\circ} \mathrm{C}$. At defined time points samples of $60 \mu \mathrm{l}$ were withdrawn and centrifuged $\left(+4{ }^{\circ} \mathrm{C}\right)$ at $6700 \mathrm{~g}$ for $3 \mathrm{~min}$. The supernatant was immediately placed in an ice-water bath. In order to estimate the amount of bound enzyme $(B)$ the activities of these supernatants (free enzyme, $F$ ) were determined as described above with soluble starch as substrate. In order to determine the total amount of enzyme $(T)$, a parallel experiment without corn starch was performed. The amount of bound enzyme $(B)$ was calculated from $B=T-F$.

Estimation of the association constant $\left(K_{\mathrm{a}}\right)$ was performed by measuring the amount of free and total enzyme as above, except that the amount of enzyme used was varied between 1.7 and $8.93 \mu \mathrm{M}$ and an equilibration time of $60 \mathrm{~min}$ was used. Each tube contained $100 \mathrm{mg}$ corn starch in $1 \mathrm{ml} 50 \mathrm{mM}$ sodium acetate, $\mathrm{pH} 4 \cdot 3$. A Langmuir type of isotherm was chosen (Takahashi et al., 1985). By plotting $1 / B$ (bound enzyme) against $1 / F$ (free enzyme) an association constant between glucoamylase $\mathrm{P}$ and corn starch could be estimated from the slope of the line according to equation (1) (from Takahashi et al., 1985). The line was fitted by using the same direct linear plot program as was used for kinetic measurements (see above).

$1 / B=1 /\left(B_{\max } \times K \times F\right)+1 / B_{\max }$

Production and purification of glucoamylase $P$ papain fragments. A sample of $1.4 \mathrm{mg}$ deglycosylated glucoamylase $P$ was incubated with $50 \mu \mathrm{g}$ papain (Sigma) in $50 \mathrm{mM}$ sodium acetate 
buffer, $\mathrm{pH} 5 \cdot 7$, at $37^{\circ} \mathrm{C}$. Samples were taken at defined time points and assayed for activity using soluble starch or pullulan as substrate as described above. After $6.5 \mathrm{~h}$ incubation, the digest was applied on a Superose 12 column as described above for the purification of deglycosylated glucoamylase P. Both peak fractions obtained were re-chromatographed on the Superose 12 column. Binding of purified glucoamylase $P$ and its fragments to raw starch was tested by incubating $3 \mathrm{nmol}$ of the corresponding protein with or without $100 \mathrm{mg}$ corn starch for $1 \mathrm{~h}$ at $4^{\circ} \mathrm{C}$. in $50 \mathrm{mM}$ sodium acetate, $\mathrm{pH} 4.3$. After centrifugation for $5 \mathrm{~min}$ at $6700 \mathrm{~g}$, binding was detected by running the samples on polyacrylamide slab gels (see below).

SDSPAGE. Polyacrylamide slab gels $(6-16 \%)$ containing $0 \cdot 1 \%$ SDS were stained with Coomassie Brilliant Blue as described by Laemmlı (1970).

Amino-terminal sequencing. This was performed by degrading the samples in a gas-pulsed liquid-phase sequencer (Kalkkinen \& Tilgmann, 1988). The released PTH-amino acids were analysed on-line by using narrow-bore reverse-phase HPLC.

\section{RESULTS}

\section{Inhibition of glucoamylase P}

Thin-layer chromatography of Zulkowsky starch showed only minor amounts of oligosaccharides with a DP of 7 , and no smaller ones (data not shown). Thus, Zulkowsky starch was taken as a high-DP soluble starch.

Preliminary results of $\alpha$-, $\beta$ - and $\gamma$-cyclodextrin inhibiting the hydrolysis of pullulan by glucoamylase $\mathrm{P}$ are shown in Table 1. They show that $\beta$-cyclodextrin was the strongest inhibitor. Inhibition studies were continued with $\beta$ cyclodextrin.

Oligosaccharides ranging from maltose to maltoheptaose, and from isomaltose to isomaltoheptaose, were tested at

Table 1. Inhibition of pullulan hydrolysis by glucoamylase $\mathbf{P}$ with different cyclodextrins

Activity was measured as described in Methods, except that the incubation temperature was $37^{\circ} \mathrm{C}$. The amount of pullulan used was $5 \mathrm{mg} \mathrm{ml}^{-1}$ and amount of enzyme $1.4 \mu \mathrm{g} \mathrm{ml}^{-1}$.

\begin{tabular}{|ccc|}
\hline Inhibitor & $\begin{array}{c}\text { Concentration } \\
\left(\mathbf{m g ~ m}^{-\mathbf{1}} \mathbf{)}\right.\end{array}$ & $\begin{array}{c}\text { Inhibition } \\
\mathbf{( \% )}\end{array}$ \\
\hline$\alpha$-Cyclodextrin & 2 & 12 \\
& $0 \cdot 2$ & 0 \\
$\beta$-Cyclodextrin & 2 & 87 \\
& $0 \cdot 2$ & 73 \\
$\gamma$-Cyclodextrin & 2 & 67 \\
& $0 \cdot 2$ & 24 \\
\hline
\end{tabular}

$5 \times K_{\mathrm{m}}$ (values from Fagerström, 1991) with $20 \mathrm{mM} \beta$ cyclodextrin for inhibition. No inhibition could be detected (data not shown).

Inhibition of pullulan hydrolysis by $\beta$-cyclodextrin was most pronounced, giving an apparent $K_{\mathrm{i}}$ of $1.4 \pm 0.3 \mu \mathrm{M}$ (Table 2). The type of inhibition was competitive (data not shown).

Hydrolysis of soluble starch and corn starch was also inhibited competitively, with apparent $K_{\mathrm{i}}$ values of $190 \pm 56 \mu \mathrm{M}$ and $13 \pm 3 \mu \mathrm{M}$ respectively for $\beta$ cyclodextrin (Table 2). The high $K_{m}$ for corn starch and dextran T-10 should be looked on with caution, since only up to about $3 \times K_{\mathrm{m}}$ values of substrate $\left(100 \mathrm{mg} \mathrm{ml}^{-1}\right)$ were used. High substrate concentrations were avoided because of possible mass transfer problems (Miranda et al., 1991). Inhibition by $\beta$-cyclodextrin of the hydrolysis of dextran T-10 appeared to be partial. As seen in Table 3, the inhibition reached maxima of $22 \%$ and $8 \%$, respectively, at substrate concentrations of about $0.3 \times K_{\mathrm{m}}$ and about $2.5 \times K_{\mathrm{m}}$ when up to $4 \mathrm{mM} \beta$-cyclodextrin was used.

\section{Binding of glucoamylase $\mathbf{P}$ to corn starch}

Binding of glucoamylase $\mathrm{P}$ to corn starch at $+4{ }^{\circ} \mathrm{C}$ reached equilibrium in $10 \mathrm{~min}$ when $3.2 \mu \mathrm{g}$ enzyme and $100 \mathrm{mg}$ corn starch were used (data not shown). The association constant of glucoamylase $\mathrm{P}$ to corn starch was estimated from the plot of $1 / F$ against $1 / B$ (where $F$ and $B$ are free and bound enzyme respectively), using an equilibration time of $60 \mathrm{~min}$. By extrapolation, a maximum binding of roughly $6 \mathrm{nmol}$ glucoamylase $\mathrm{P}$ could be calculated, corresponding to about $420 \mu \mathrm{g}$ glucoamylase $\mathrm{P}$ per $100 \mathrm{mg}$ corn starch. From the slope of this plot a $K_{\mathrm{a}}$ value of $3.4 \times 10^{5} \mathrm{M}^{-1}$ for glucoamylase $\mathrm{P}$ binding to corn starch could be obtained.

\section{Activity of fragments of glucoamylase $P$}

Partial hydrolysis of deglycosylated glucoamylase P with papain was followed by SDS-PAGE (Fig. 1a) and by activity measurements using soluble starch and pullulan as substrate (Table 4). The initial hydrolysis of the native deglycosylated $63 \mathrm{kDa}$ glucoamylase $\mathrm{P}$ was rapid, and seemed to reach a plateau in about 3 to $6 \mathrm{~h}$. During prolonged incubation (up to $30 \mathrm{~h}$ ) the $53 \mathrm{kDa}$ band that appeared was further digested to a $51 \mathrm{kDa}$ band. The smallest product of the digestion had a molecular mass of $14 \mathrm{kDa}$ as estimated from SDS-PAGE. The initial velocity of soluble starch digestion slightly increased (by about $8 \%$ ) during incubation, whereas that for pullulan decreased by about $85 \%$. After $6.5 \mathrm{~h}$ incubation the large fragment, glucoamylase $\mathrm{P}_{\mathrm{c}}$ (the 'core'), was separated by gel-exclusion chromatography from the small fragment, glucoamylase $P_{t}$ (the 'tail'). The amino-terminal sequence of glucoamylase $\mathrm{P}_{\mathrm{c}}$ obtained was identical with that of native glucoamylase P (Asp-Leu-Ser-Ser-Phe-Ile-Ala-; Fagerström et al., 1990) and corresponded to the amount of protein used in sequencing. No other sequences could 
Table 2. Apparent $K_{\mathrm{m}}$ and $K_{\mathrm{i}}$ values obtained for glucoamylase $\mathbf{P}$ with different substrates and $\beta$ cyclodextrin as inhibitor

The estimates of $K_{\mathrm{i}}$ are expressed as means \pm range from the values obtained from Lineweaver-Burk and Dixon plots.

\begin{tabular}{|lcc|}
\hline Substrate & $\begin{array}{c}\boldsymbol{K}_{\mathrm{m}} \\
\left(\mathbf{m g ~ m}^{-\mathbf{1}}\right)\end{array}$ & $\boldsymbol{K}_{\mathbf{i}}(\boldsymbol{\mu M})$ \\
\hline Soluble starch & $0 \cdot 06$ & $190 \pm 56$ \\
Pullulan & $0 \cdot 11$ & $1 \cdot 4 \pm 0 \cdot 3$ \\
Dextran T-10 & $29 \cdot 3$ & $*$ \\
Corn starch & $31 \cdot 0$ & $13 \pm 3$ \\
\hline
\end{tabular}

* No apparent $K_{\mathrm{j}}$ could be obtained for dextran T-10 (see Results and Table 3).

be detected. The amino-terminal sequence of glucoamylase $P_{t}$ was Ser-Ser-x-Gln-Val-Ser-Ile-Thr-Phe-Asn-, corresponding to residues 474 to 483 of the intact glucoamylase P sequence (Vainio et al., 1993).

Binding of glucoamylase $\mathrm{P}_{t}$, glucoamylase $\mathrm{P}_{\mathrm{c}}$ and glucoamylase $\mathrm{P}$ to corn starch was tested by incubating purified samples with corn starch in the ratio $3 \mathrm{nmol}$ per $100 \mathrm{mg}$ (half saturation of glucoamylase P). Binding of gluco-
Table 3. Inhibition by $\beta$-cyclodextrin of dextran T-10 hydrolysis by glucoamylase $\mathbf{P}$

Activity was measured in $50 \mathrm{mM}$ sodium acetate, $\mathrm{pH} 4 \cdot 3$, at $30^{\circ} \mathrm{C}$, as described in Methods. The amount of enzyme used was $1 \cdot 75 \mu \mathrm{g} \mathrm{ml} l^{-1}$.

\begin{tabular}{|ccc|}
\hline $\begin{array}{c}\text { Concn of } \\
\boldsymbol{\beta} \text {-cyclodextrin } \\
(\boldsymbol{\mu} \mathbf{M})\end{array}$ & $\begin{array}{c}\text { Concn of } \\
\text { dextran } \\
\mathbf{T}-10 \\
\left(\mathbf{m g ~ m}^{-1}\right)\end{array}$ & $\begin{array}{c}\text { Inhibition } \\
(\%)\end{array}$ \\
\hline $0 \cdot 1$ & 75 & 4 \\
$0 \cdot 1$ & 10 & 6 \\
2 & 75 & 6 \\
2 & 10 & 14 \\
10 & 75 & 8 \\
10 & 10 & 22 \\
4000 & 75 & 8 \\
4000 & 10 & 21 \\
\hline
\end{tabular}

amylase $\mathrm{P}$ and $\mathrm{P}_{\mathrm{t}}$ to corn starch was apparent, but no binding of glucoamylase $\mathrm{P}_{\mathrm{c}}$ could be detected (Fig. 1b).

Estimations of the apparent $K_{\mathrm{m}}$ and $k_{\text {cat }}$ values of deglycosylated glucoamylase $\mathrm{P}$, glucoamylase $\mathrm{P}_{\mathrm{c}}$ and a

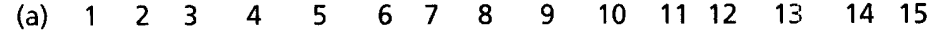

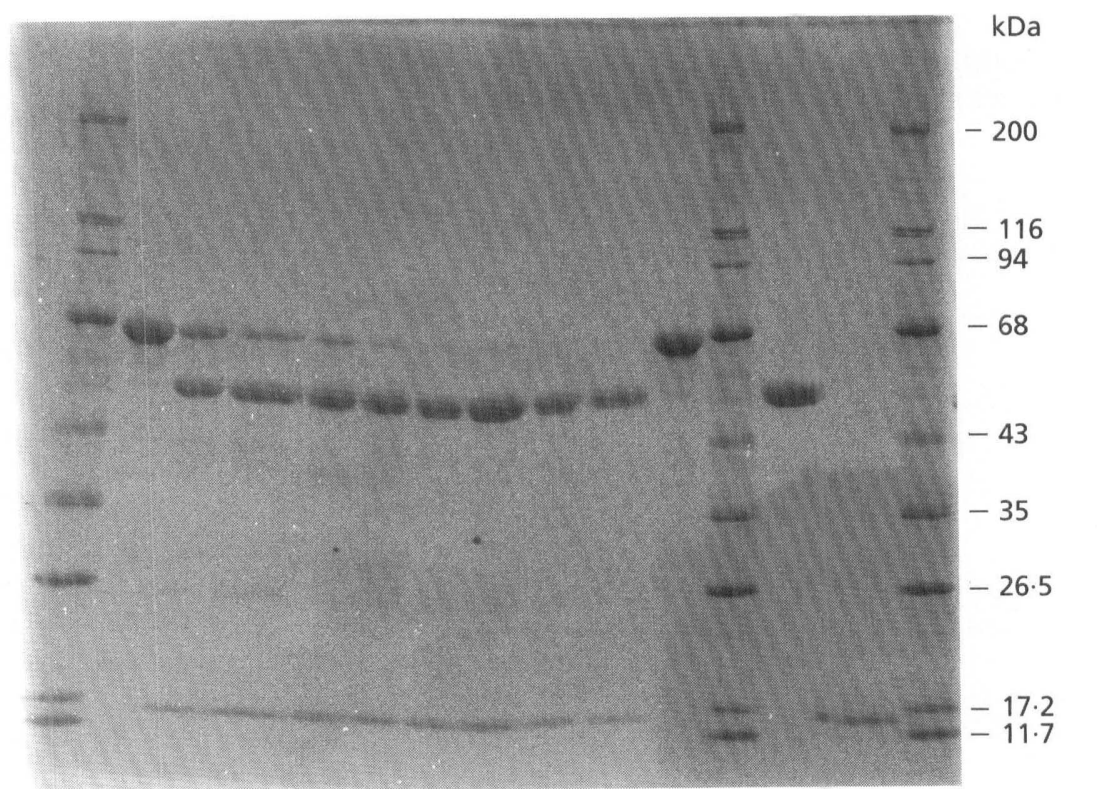

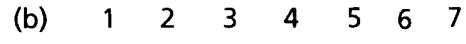

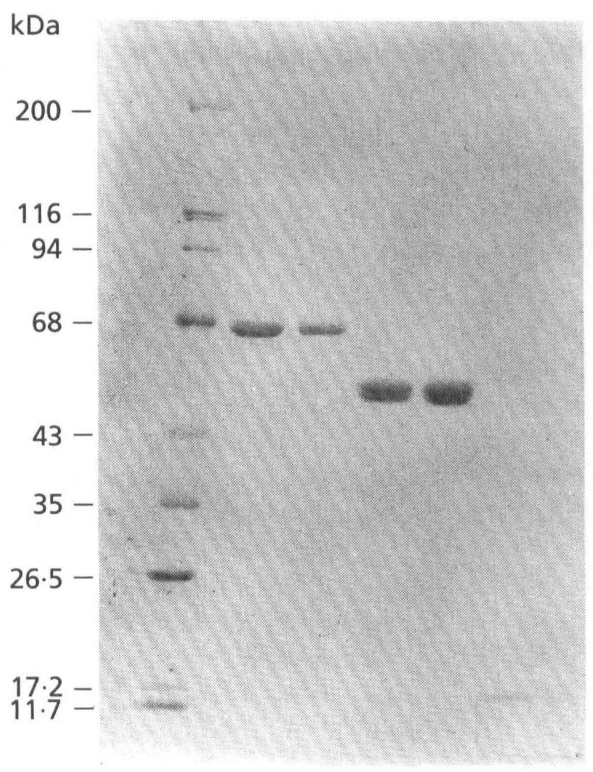

Fig. 1. SDS-PAGE analysis of glucoamylase $P$ digested with papain. (a) Deglycosylated glucoamylase $P$ (1.4 mg) was incubated with $25 \mu \mathrm{g}$ papain $\mathrm{ml}^{-1}$ in $50 \mathrm{mM}$ sodium acetate, $\mathrm{pH} 5 \cdot 7$, at $37^{\circ} \mathrm{C}$ for the following times. Lane $2,0 \mathrm{~min}$; lane 3, $10 \mathrm{~min}$; lane 4, $30 \mathrm{~min}$; lane 5, $60 \mathrm{~min}$; lane 6, 3.5 h; lane 7,6.5 h; lane 8, $14 \mathrm{~h}$; lane 9, $24 \mathrm{~h}$; lane 10, $30 \mathrm{~h}$; lane 11, deglycosylated glucoamylase $P$ kept at $37^{\circ} \mathrm{C}$ for $30 \mathrm{~h}$. Lanes 13 and 14 , purified glucoamylase $P_{c}$ and glucoamylase $P_{t}$ respectively. Lanes 1,12 and 15 , molecular mass markers. (b) Purified glucoamylase $P, P_{c}$ and $P_{t}$ were incubated at $4{ }^{\circ} C$ with or without corn starch in a ratio of $3 \mathrm{nmol}$ per $100 \mathrm{mg}$ each, as described in Methods. Lanes 2, 4 and 6, glucoamylase $P, P_{c}$ and $P_{t}$, respectively, without corn starch; lanes 3,5 and 7 , the respective samples in the presence of corn starch; lane 1, molecular mass markers. 
Table 4. Relative activity of glucoamylse $P$ towards $5 \mathrm{mg}$ soluble starch $\mathrm{ml}^{-1}$ or pullulan during digestion by papain

Deglycos! lated glucoamylase $\mathrm{P}\left(1.4 \mathrm{mg} \mathrm{ml}^{-1}\right)$ and papain $\left(50 \mu \mathrm{g} \mathrm{ml}{ }^{1}\right)$ were incubated at $37^{\circ} \mathrm{C}$ in $50 \mathrm{mM}$ sodium acetate, $\mathrm{pH}$ 5.7. Samples at defined time points were assayed for activity using either soluble starch or pullulan as substrate $\left(5 \mathrm{mg} \mathrm{ml}^{-1}\right.$ each) as described in Methods.

\begin{tabular}{|ccc|}
\hline $\begin{array}{c}\text { Incubation } \\
\text { time } \\
\text { (h) }\end{array}$ & \multicolumn{2}{c|}{$\begin{array}{c}\text { Relative activity } \\
\mathbf{( \% )}\end{array}$} \\
\cline { 2 - 3 } & $\begin{array}{c}\text { Soluble } \\
\text { starch }\end{array}$ & Pullulan \\
\hline 0 & 100 & 100 \\
$0 \cdot 17$ & 109 & 85 \\
$3 \cdot 5$ & 109 & 17 \\
$6 \cdot 5$ & 109 & 16 \\
$10 \cdot 0$ & 106 & 14 \\
$14 \cdot 0$ & 102 & 14 \\
\hline
\end{tabular}

mixture of glucoamylase $\mathrm{P}_{\mathrm{c}}$ and glucoamylase $\mathrm{P}_{t}$ in a $1: 2$ molar ratio with different substrates are shown in Table 5. No apparent changes in $K_{\mathrm{m}}$ and $k_{\text {cat }}$ could be seen for the malto- and isomalto-oligosaccharides tested. There was a tenfold increase in $K_{\mathrm{m}}$ for soluble starch when glucoamylase $P_{c}$ was used, without any change in $k_{\text {cat }}$. Glucoamylase $\mathrm{P}_{\mathrm{c}}$ acting on pullulan showed a 400 -fold increase in $K_{\mathrm{m}}$, but no change in $k_{\text {cat }}$. Changes of the kinetic constants upon adding glucoamylase $\mathrm{P}_{\mathrm{t}}$ to glucoamylase $P_{c}$ were within the $S D$ values of the measurements.

The apparent $K_{\mathrm{m}}$ and $k_{\text {cat }}$ for glucoamylase $\mathrm{P}_{\mathrm{c}}$ towards corn starch could not be estimated because of the low activity.

The progress curves (Fig. 2) of glucoamylase P acting on corn starch showed an initial 'burst' followed by a linear steady-state rate. Possible inactivation of glucoamylase P in reaction mixtures was studied by measuring the activity of the mixtures towards soluble starch after incubation in the presence or absence of 20 or $100 \mathrm{mg}$ corn starch $\mathrm{ml}^{-1}$ (Fig. 2). In all three cases about $40 \%$ of the original activity disappeared during $3 \mathrm{~h}$. In reaction mixtures containing $100 \mathrm{mg}$ soluble starch $\mathrm{ml}^{-1}$ no inactivation could be detected, and the progress curves were linear (not shown).

Addition of fresh substrate $\left(100 \mathrm{mg} \mathrm{ml}^{-1}\right)$ during corn starch hydrolysis $\left(100 \mathrm{mg}\right.$ corn starch $\mathrm{ml}^{-1}$ and $50 \mu \mathrm{g}$ glucoamylase $\mathrm{P} \mathrm{ml}^{-1}$ ) resulted in a new 'burst' followed by a new steady-state (Fig. 3). This addition diluted the reaction mixture by $1: 1$. Roughly the same steady state was achieved by diluting the original mixture by $1: 1$ with buffer. Addition of more enzyme to $50 \mathrm{mg}$ corn starch $\mathrm{ml}^{-1}$ caused a smaller 'burst' followed by a new steady-state rate.

The plots of the linear steady-state rate against the amount of glucoamylase $\mathrm{P}$ were linear at enzyme to substrate ratios above $0 \cdot 25 \mu \mathrm{g}$ per $\mathrm{mg}$ corn starch (Fig. 4). A much smaller linear steady-state rate was obtained with glucoamylase $\mathrm{P}_{\mathrm{c}}$ hydrolysing corn starch.

\section{Table 5. Kinetic constants of papain-digested and undigested glucoamylase $P$}

The enzume preparations were purified as described in the text and the kinetic constants were estimated with a variety of substrates. Glucoamylase $\mathrm{P}$, deglycosylated undigested glucoamylase $\mathrm{P}$; glucoamylase $\mathrm{P}_{\text {c }}$, purified core domain of glucoamylase $\mathrm{P}$; glucoamylase $P_{c}+P_{t}, 1$ mol glucoamylase $P_{c}$ and 2 mol purified raw-starch-binding domain, glucoamylase $P_{t}$. Estimates are means \pm range of at least two independent experiments, except for isomaltoheptaose. The $K_{\mathrm{m}}$ of pullulan with glucoamylase $\mathrm{P}_{\mathrm{c}}$ and the combination of glucoamylase $\mathrm{P}_{t}$ and $\mathrm{P}_{t}$ could not be measured accurately, since the maximum amount of substrate used was only $2-3 \times K_{\mathrm{m}}$.

\begin{tabular}{|c|c|c|c|c|c|c|}
\hline \multirow[t]{2}{*}{ Substrate } & \multicolumn{2}{|c|}{ Glucoamylase P } & \multicolumn{2}{|c|}{ Glucoamylase $P_{c}$} & \multicolumn{2}{|c|}{ Glucoamylase $P_{c}+P_{t}$} \\
\hline & $K_{\mathrm{m}}$ & $k_{\text {cat }} *$ & $K_{\mathrm{m}}$ & $k_{\mathrm{cat}} *$ & $K_{\mathrm{m}}$ & $k_{\mathrm{cat}}{ }^{*}$ \\
\hline Soluble starch $\dagger$ & $0 \cdot 06 \pm 0 \cdot 01$ & $30 \pm 1$ & $0 \cdot 67 \pm 0 \cdot 14$ & $29 \pm 1$ & $0 \cdot 78 \pm 0 \cdot 20$ & $30 \pm 1$ \\
\hline Pullulan $†$ & $0 \cdot 10 \pm 0 \cdot 02$ & $18 \pm 2$ & $\sim 40$ & $18 \pm 1$ & $\sim 50$ & $17 \pm 1$ \\
\hline Maltosef & $1 \cdot 8 \pm 0 \cdot 1$ & $5 \cdot 8 \pm 0 \cdot 1$ & $2 \cdot 1 \pm 0 \cdot 1$ & $6 \cdot 1 \pm 0 \cdot 2$ & $2 \cdot 0 \pm 0 \cdot 2$ & $5 \cdot 6 \pm 0 \cdot 2$ \\
\hline Maltoheptaose $\ddagger$ & $0 \cdot 26 \pm 0.03$ & $38 \pm 2$ & $0 \cdot 25 \pm 0 \cdot 04$ & $37 \pm 2$ & $0 \cdot 20 \pm 0 \cdot 02$ & $40 \pm 2$ \\
\hline Isomaltose $\ddagger$ & $21 \pm 1$ & $2 \cdot 8 \pm 0 \cdot 3$ & $22 \pm 2$ & $3 \cdot 0 \pm 0 \cdot 2$ & $23 \pm 1$ & $2 \cdot 8 \pm 0 \cdot 1$ \\
\hline Isomaltoheptaose $\ddagger$ & $4 \cdot 5$ & 11 & $4 \cdot 8$ & 12 & $4 \cdot 6$ & 12 \\
\hline Corn starcht & $37 \pm 5$ & $0.62 \pm 0.07$ & ND & ND & ND & ND \\
\hline
\end{tabular}

ND, Not determined.

$* k_{\text {cat }}$ expressed as $\mu \mathrm{mol} \mathrm{min}^{-1} \mathrm{mg}^{-1}$.

$\dagger K_{m}$ expressed as $\mathrm{mg} \mathrm{m}^{-1}$.

$\ddagger K_{\mathrm{m}}$ expressed as $\mathrm{mM}$. 

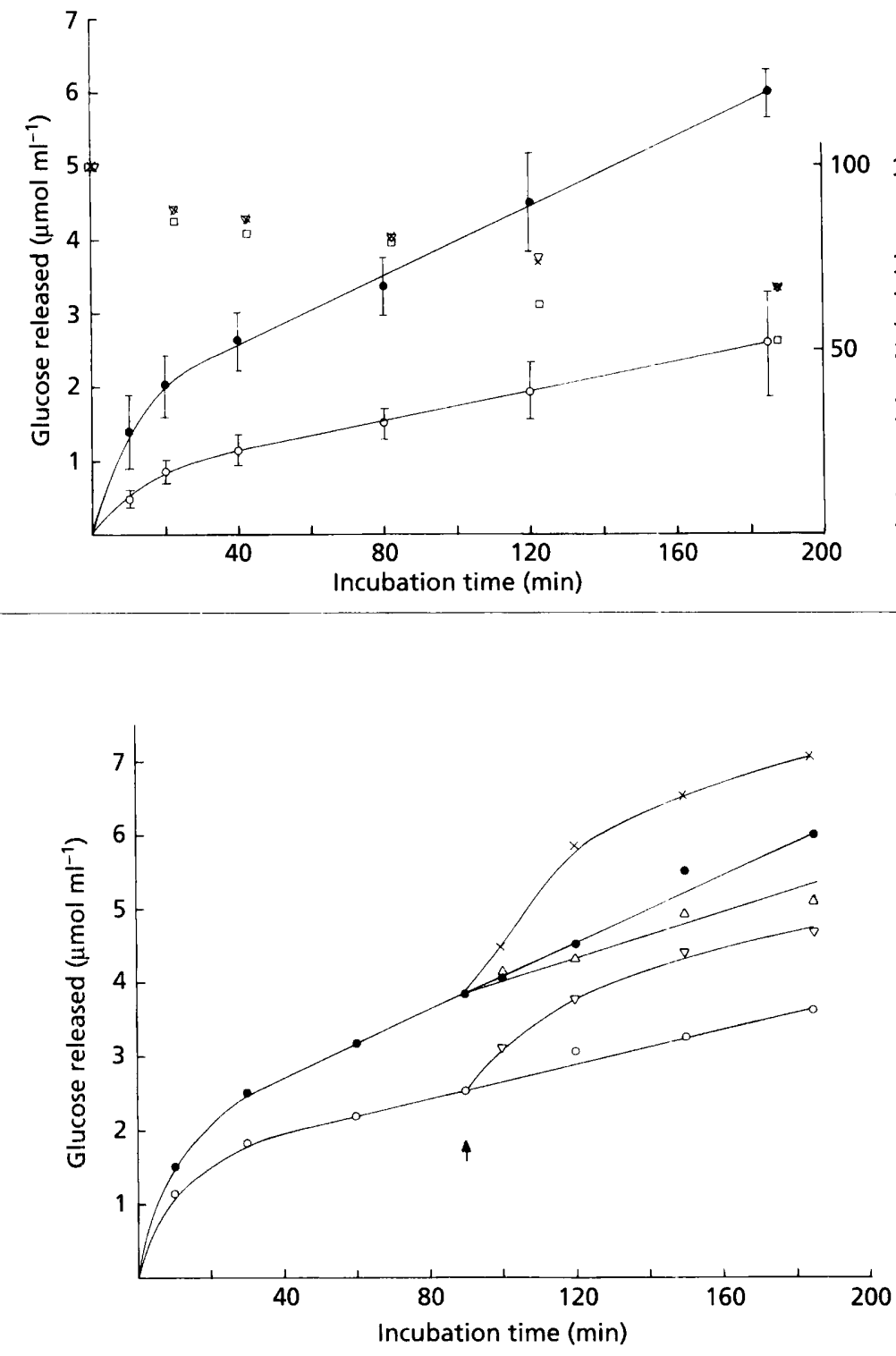

Fig. 2. Progress curves for glucoamylase $P$ acting on corn starch. Samples of $50 \mu \mathrm{g}$ glucoamylase $P \mathrm{ml}^{-1}$ were incubated with $20 \mathrm{mg}(0)$ and $100 \mathrm{mg}(0)$ corn starch $\mathrm{ml}^{-1}$ respectively at $30^{\circ} \mathrm{C}$ in $50 \mathrm{mM}$ sodium acetate, $\mathrm{pH} 4 \cdot 3$. Released glucose was measured at defined time points as described in Methods. The error bars represent deviations of an average of at least three independent experiments. Activity towards soluble starch was measured during incubations with: $\nabla$ $20 \mathrm{mg}$ corn starch $\mathrm{ml}^{-1} ; \square, 100 \mathrm{mg}$ corn starch $\mathrm{ml}^{-1}$ and $x$, without corn starch. Relative activities were calculated.

Fig. 3. Effect of dilution, addition of substrate and enzyme on the linear steadystate rate. A sample of $50 \mu \mathrm{g}$ glucoamylase $P$ $\mathrm{ml}^{-1}$ was incubated with $100 \mathrm{mg}$ corn starch $\mathrm{ml}^{-1}$ at $30^{\circ} \mathrm{C}$ in $50 \mathrm{mM}$ sodium acetate, $\mathrm{pH} 4.3$ (O). After $90 \mathrm{~min}$, part of the incubation mixture was withdrawn and diluted $(1: 1)$ with buffer $(\triangle)$. To another part was added $100 \mathrm{mg}$ corn starch $\mathrm{ml}^{-1}(x)$, resulting in a dilution of the mixture by $1: 1$. An additional sample of $50 \mu \mathrm{g} \mathrm{ml}^{-1}$ was incubated with $50 \mathrm{mg}$ corn starch $\mathrm{ml}^{-1}(O)$. After $90 \mathrm{~min}$, part of the mixture $(500 \mu \mathrm{l})$ was withdrawn, and a concentrated sample of glucoamylase $\mathrm{P}(50 \mu \mathrm{g}$ in $10 \mu \mathrm{l})$ was added $(\nabla)$.

\section{DISCUSSION}

Belshaw \& Williamson (1990) reported an association constant of $3.8 \times 10^{5} \mathrm{M}^{-1}$ between $A$. niger glucoamylase (form G1) and corn starch, whereas Dalmia \& Nikolov (1991) found a constant one order of magnitude higher. Takahashi et al. (1985) reported a value of $1.2 \times 10^{5} \mathrm{M}^{-1}$ for Rbizopus glucoamylase (G1). The association constant of $3.4 \times 10^{5} \mathrm{M}^{-1}$ obtained in this study for glucoamylase $\mathrm{P}$ from Hormoconis resinae is in broad agreement with those values. The binding capacity of corn starch for glucoamylase $P$ was about $4 \mathrm{mg}$ protein $(\mathrm{g} \text { corn starch })^{-1}$, close to the values reported for $A$. niger glucoamylase $\mathrm{G}$ ! [1.6-4.3 mg protein (g corn starch) ${ }^{-1}$; Dalmia \& Nikolov, 1991]. This suggests that glucoamylase P from Hormoconis resinae also contains a 'high affinity' raw-starch-binding; domain. Removal of this domain did not alter the specificity towards small malto and isomalto oligo. saccharides (Table 5). Apparently the raw-starch-binding domain is not involved in the debranching activity of glucoamylase P.

Studies on the separated binding domain of $A$. niger glucoamylase (Belshaw \& Williamson, 1991) have revealed that it binds $2 \mathrm{~mol} \beta$-cyclodextrin (mol protein $)^{-1}$. Further, this domain seems to contain at least two subsites, of which one (s1) binds maltooligosaccharides, raw starch, dextrans and $\beta$-cyclodextrin (Belshaw \& Williamson, 1993). The other subsite (s2) would bind the proposed transition state analogue (glucono-1,5-lactone) and also contributes to dextran binding. The low $K_{\mathrm{i}}(1 \cdot 4 \pm 0 \cdot 3 \mu \mathrm{M})$ for $\beta$-cyclodextrin inhibiting pullulan hydrolysis by glucoamylase $\mathrm{P}$ is close to the $K_{\mathrm{d}}$ value of $\beta$-cyclodextrin from the raw-starchbinding domain of $A$. niger glucoamylase $(1.68 \mu \mathrm{M}$ for the second ligand; Belshaw \& Williamson, 1991). Consider- 


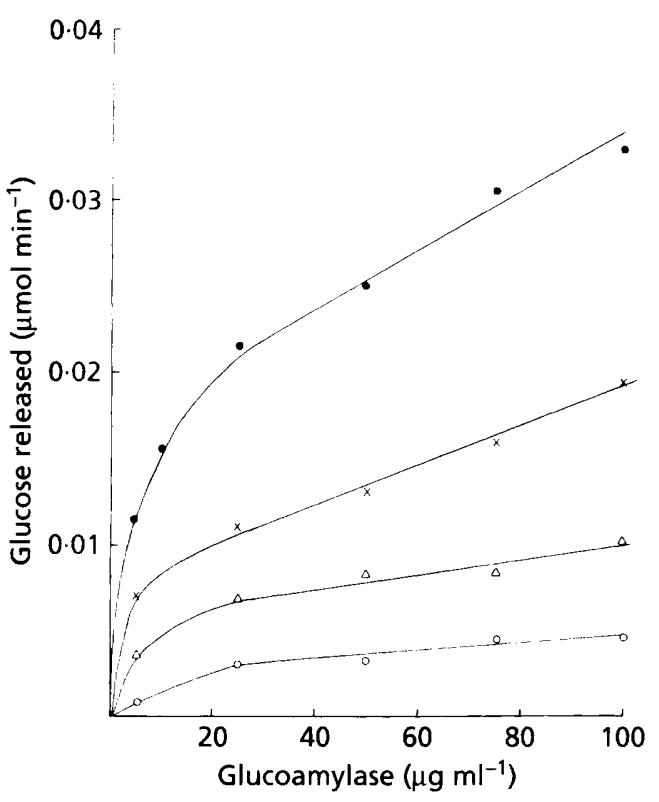

Fig. 4. Effect of enzyme concentration on corn starch digestion. Steady-state rates of different amounts of glucoamylase $P$ hydrolysing $20 \mathrm{mg}(x)$ and $100 \mathrm{mg}^{(0)}$ corn starch $\mathrm{ml}^{-1}$ in $50 \mathrm{mM}$ sodium acetate, $\mathrm{pH} 4 \cdot 3$, at $30^{\circ} \mathrm{C}$ were measured. The same measurements were performed with glucoamylase $P_{c}(O$ and $\triangle$, respectively).

ing the high homology between these glucoamylases (except for the TS region), this suggests that the $K_{\mathrm{i}}$ reflects binding of $\beta$-cyclodextrin to an s1 site in glucoamylase $\mathrm{P}$, and so that pullulan also binds to this site in the raw-starch-binding domain. The big increase of $K_{\mathrm{m}}(400-$ fold) upon removal of the tail of glucoamylase P supports this proposal. This increase in $K_{\mathrm{m}}$ explains the apparent loss of activity towards pullulan during partial proteolysis with papain (Table 4), because the substrate concentration used changes from about $50 \times K_{\mathrm{m}}$ to about $0 \cdot 1 \times K_{\mathrm{m}}$.

A possible explanation for the partial inhibition observed with dextran T-10 as substrate could be that subsite $\mathrm{s} 1$ becomes fully occupied with $\beta$-cyclodextrin, compelling dextran T-10 to bind only to a subsite 22 of the raw-starchbinding domain, still enabling hydrolysis to occur.

The apparent $K_{\mathrm{i}}$ of $\beta$-cyclodextrin for glucoamylase $\mathrm{P}$ acting on corn starch $(13 \pm 3 \mu \mathrm{M})$ and the type of inhibition are similar to those reported for the isolated raw-starch-binding domain of $A$. niger glucoamylase (competitive, apparent $K_{\mathrm{i}} 11.0 \pm 1.9 \mu \mathrm{M}$; Bellshaw \& Williamson, 1991).

Hydrolysis of shorter malto- and isomaltooligosaccharides (DP 2-7) with glucoamylase P was not inhibited by $\beta$-cyclodextrin. This has also been shown for Aspergillus glucoamylase acting on malto-oligosaccharides (Fukuda et al., 1992). With glucoamylase $\mathrm{P}, \beta$-cyclodextrin inhibits the hydrolysis of soluble starch with a $K_{\mathrm{i}}$ one order of magnitude lower than reported for Chlara paradoxa (Monma et al., 1989) and Aspergillus awamori (Fukuda et al., 1992) glucoamylases.

The rapid deceleration during the first $20 \mathrm{~min}$ of corn starch hydrolysis to a steady-state rate did not seem to be solely a result of inactivation of the enzyme (Fig. 2). Inactivation of about $15 \%$ in $20 \mathrm{~min}$ would not be expected to slow down the rate to one-fifth. Addition of fresh substrate caused a new burst, suggesting that the deceleration was not due to product inhibition. Addition of fresh enzyme to mixtures of low enzyme/substrate ratios caused a new burst, but smaller than the first. These results suggest that the initial rate (the burst) is mainly due to some minor but reactive component(s) of the corn starch, such as insoluble structures or residues of soluble components, whereas the steady-state rate reflects hydrolysis of large corn starch granules.

The hydrolysis rate of corn starch with glucoamylase $\mathrm{P}_{\mathrm{c}}$ was much smaller than with glucoamylase $P$ (Fig. 4). Small amounts (about 1-3\%) of intact glucoamylase $\mathrm{P}$ as an impurity in glucoamylase $\mathrm{P}_{\mathrm{c}}$ preparations could however result in about the same degree of hydrolysis as obtained. Thus, no definite proof of glucoamylase $\mathrm{P}_{\mathrm{c}}$ digesting corn starch could be obtained.

Incubations of $1 \mathrm{mg}$ deglycosylated glucoamylse $\mathrm{P} \mathrm{ml}^{-1}$ with $20 \mathrm{mg}$ corn starch $\mathrm{ml}^{-1}$ at $30^{\circ} \mathrm{C}$ for $2.5 \mathrm{~d}$ resulted in about $10 \%$ hydrolysis as estimated from the theoretical value (unpublished data). This is in agreement with the results obtained with $A$. awamori var. kawachi glucoamylase G1 hydrolysing corn starch (Hayashida et al., 1989). This slow hydrolysis of corn starch has to be taken into account when industrial applications involving raw starch hydrolysis are planned. An important effect of the raw-starch-binding domain from an industrial point of view is that it lowers the $K_{\mathrm{m}}$ of large soluble polysaccharide substrates, resulting in efficient hydrolysis at low concentrations.

Sequence alignment of the raw-starch-binding and linker region of glucoamylase $\mathrm{P}$ with other glucoamylases is shown in Fig. 5. There are nine consensus sequence amino acids present in glucoamylase $P$ out of 11 proposed for different starch-degrading enzymes (Svensson et al., 1989). The absence of the highly glycosylated TS region in glucoamylase $\mathrm{P}$ is apparent.

The role of the TS region in hydrolysis of insoluble substrates has led to conflicting interpretations. Hayashida et al. (1989) suggested that this TS region was important in raw starch digestion by glucoamylase G1 from $A$. awamori var. kawachi. Later results have suggested a minor effect of this region on binding of the enzyme to raw starch (Williamson et al., 1992). From the results obtained here, it seems that a long TS region is not needed for efficient binding of glucoamylase to raw starch. However its effect on efficient hydrolysis of raw starch may still be of importance.

The apparently short linker region in glucoamylase $\mathrm{P}$ may result in less flexibility between the core and tail domain. 

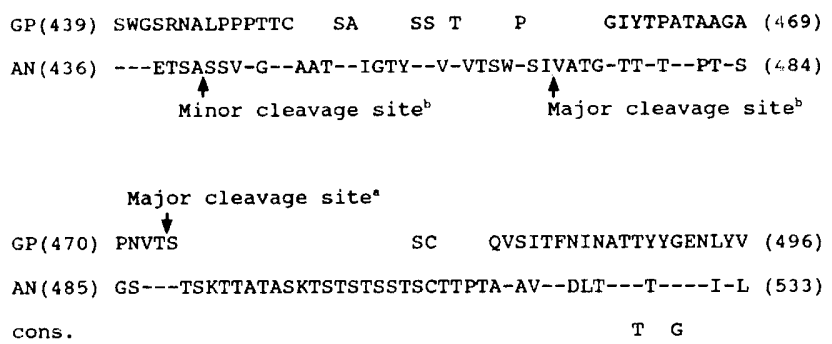

GP(497) IGNSSDLGAWNIADAYPLSASAYTQDRPLWSAAIPLNAGEVISYQYVRQ (545)

AN (534) V-SI-Q--D-ETS-GIA---DK--SSD---YVTVT-P---SFE-KFI-I (582)

$\begin{array}{lllll}\text { cons. G L W } & \text { P W }\end{array}$

GP(546) EDCDQPYIYETVNRTLTVP ACGGAAVTTDDAWMGPVGSSGNC*

AN (583) -SD-SVEWESDP--EY---Q---TSTA-VT-T-R*

cons.

W N

Fig. 5. Sequence alignment of glucoamylase $P$ and $A$. niger glucoamylase G1. The consensus (cons.) sequence of different glucoamylases (Svensson et al., 1989) as well as the linker region (from Stoffer et al., 1993) are aligned. Lines represent identity; empty spaces represent gaps in the alignment. Numbering is according to the native amino acid sequence. GP, glucoamylase $\mathrm{P} ; \mathrm{AN}, A$. niger glucoamylase $\mathrm{G1}{ }^{2}{ }^{2}$, cleavage site in glucoamylase $P$ by papain digestion (this paper). ${ }^{b}$, cleavage sites found by subtilisin digestion of $A$. niger glucoamylase $\mathrm{G} 1$ (Stoffer et al., 1993).

Trials to crystallize this glucoamylase in an intact form with the tail domain are under way.

\section{ACKNOWLEDGEMENTS}

I thank Mr John Denslow for computer programming and Dr John Londesborough for critical reading of the manuscript. Dr Nisse Kalkkinen is also acknowledged for amino acid sequencing and Ms Arja Mikkelinen for art work.

\section{REFERENCES}

Abe, J., Nakajima, K. \& Hizukuri, S. (1990). Alteration of the properties of Aspergillus sp. K-27 glucoamylase on limited proteolysis with subtilisin. Carbobydr Res 203, 129-138.

Aleshin, A., Golubev, A., Firsov, L. M. \& Honzatko, R. B. (1992). Crystal Structure of glucoamylase from Aspergillus awamori var. X100 to 2.2 Ä Resolution. J Biol Chem 267, 19291- 19298.

Belshaw, N. J. \& Williamson, G. (1990). Production and purification of a granular-starch-binding domain of glucoamylase 1 from Aspergillus niger. FEBS Lett 269, 350-353.

Belshaw, N. J. \& Williamson, G. (1991). Interaction of $\beta$ cyclodextrin with the granular starch binding domain of glucoamylase. Biochim Bioplyys Acta 1078, 117-120.

Belshaw, N. J. \& Williamson, G. (1993). Specificity of the binding domain of glucoamylase 1. Eur J Biochem 211, 717-724.

Cattlay, B. J. (1979). Pullulan synthesis by Aureobasidum pullulans. In Microbial Polysaccharides and Polysaccharases, pp. 69-84. Edited by R. C. E. Berkeley, G. W. Gooday \& D. C. Ellwood. London: Academic Press.
Cornish-Bowden, A. (1977). An automatic method for deriving steady-state rate equations. Biochem J 165, 55-59.

Dalmia, B. K. \& Nikolov, Z. L. (1991). Characterization of glucoamylase adsorption to raw starch. Enzyme Microb Technol 13, 982990.

Fagerström, R. (1991). Subsite mapping of Hormoconis resinat glucoamylases and their inhibition by gluconolactone. $J G^{\prime \prime} n$ Microbiol 137, 10011008.

Fagerström, R. (1994). Purification and specificity of recombinant Hormoconis resinat glucoamylase $\mathrm{P}$ and endogenous glucoamylase from Trichoderma reesei. Enzyme Microb Tecbnol 16, 36-42.

Fagerström, R., Vainio, A., Suoranta, K., Pakula, T., Kalkkinen, N. \& Torkkeli, H. (1990). Comparison of two glucoamylases from Hormoconis resinae. J Gen Microbiol 136, 913-920.

Fukuda, K., Teramoto, Y., Goto, M., Sakamoto, J., Mitsuiki, S. \& Hayashida, S. (1992). Specific inhibition by cyclodextrins of raw starch digestion by fungal glucoamylase. Biosci Biotechnol Biochem 56, 556-559.

Hansen, S. A. (1975). Thin-layer chromatographic method for identification of oligosaccharides in starch hydrolyzates. J Chromatogr 105, 338-390.

Hayashida, S., Nakahara, K., Kanlayakrit, W., Hara, T. \& Teramoto, Y. (1989). Characteristics and function of raw-starch-affinity site on Aspergillus awamori var. kawacbi glucoamylase I molecule. Agric Biol Chem 53, 143-149.

Hayashida, S., Teramoto, Y., Inoue, T. \& Mitsuiki, S. (1990). Occurrence of an affinity site apart from the active site on the rawstarch-binding but non-raw-starch-adsorbable Bacillus subtilis 65 $\alpha$-amylase. Appl Environ Microbiol 56, 2584-2586.

Joutsjoki, V. V. \& Torkkeli, T. K. (1992). Glucoamylase P gene of Hormoconis resinae: Molecular cloning, sequencing and introduction into Trichoderma reesei. FEMS Microbiol Lett 99, 237-244.

Joutsjoki, V., Torkkeli, T. \& Nevalainen, H. (1993). Transformation of Trichoderma reesei with the Hormoconis resinae glucoamylase $\mathrm{P}$ $(\mathrm{gamP})$ gene: production of a heterologous glucoamylase by Trichoderma reesei. Curr Genet 24, 223-228.

Kalkkinen, N. \& Tilgmann, C. (1988). A gas-pulsed-phase sequencer constructed from a Beckman $890 \mathrm{D}$ instrument by using Applied Biosystems delivery and cartridge blocks. J Protein Chem 7, 242-243.

Kobayashi, M., Takagi, S., Matsuda, K. \& Ichishima, E. (1988). Inhibition of $\alpha$-amylase and phosphorylases by cyclodextrindialdehyde. Agric Biol Chem 52, 2703-2708.

Kraulis, P. J., Clore, G. M., Nilges, M., Jones, T. A., Pettersson, G., Knowles, J. \& Gronenborn, A. M. (1989). Determination of the three-dimensional structure of the $\mathrm{C}$-terminal domain of cellobiohydrolase I from Trichoderma reesei. A study using nuclear magnetic resonance and hybrid distance geometry-dynamical simulated annealing. Biochemistry 28, 7241-7257.

Laemmli, U. K. (1970). Cleavage of structural proteins during the assembly of the head of bacteriophage T4. Nature 227, 680-685.

Marshall, J. J. (1973). Inhibition of pullulanase by Shardinger dextrins. FEBS Lett 37, 269-273.

McCleary, B. V. \& Anderson, M. A. (1980). Hydrolysis of $\alpha$-Dglucans and $\alpha$-D-gluco-oligosaccharides by Cladosporium resinae glucoamylases. Carbohydr Res 86, 77-96.

Meagher, M. M., Nikolov, Z. L. \& Reilly, P. J. (1989). Subsite mapping of Aspergillus niger glucoamylase I and II with malto- and isomaltooligosaccharides. Biotechnol Bioeng 34, 681-688.

Medda, S., Saha, B. C. \& Ueda, S. (1982). Raw starch adsorption and elution behavior of glucoamylase I of black Aspergillus. $J$ Fermentation Technol 60, 261-264. 
Melasniemi, H. (1987). Effect of carbon source on production of thermostable $\alpha$-amylase, pullulanase and $\alpha$-glucosidase by Clostriditm thermobydrosulfuricum. J Gen Microbiol 133, 883-890.

Miranda, M., Murado, M. A., Sanroman, A. \& Lema, J. M. (1991). Mass transfer control of enzymatic hydrolysis of polysaccharides by glucoamilase. Enzyme Microb Tecbnol 13, 142-147.

Monma, M., Yamamoto, Y. \& Kainuma, K. (1989). Subsite structure of Chlara paradoxa glucoamylase and interaction of the glucoam lase with cyclodextrins. Agric Biol Chem 53, 1503-1508.

Rouvinen, J., Bergfors, T., Teeri, T., Knowles, J. K. C. \& Jones, T. A. (1990). The three dimensional structure of cellobiohydrolase II from Trichoderma reesei. Science 249, 380-386.

Scopes, R. K. (1974). Measurement of protein by spectrophotometry at $205 \mathrm{~nm}$. Anal Biocbem 59, 277-282.

Savel'ev, A. N., Sergeev, V. R. \& Firsov, L. M. (1989). Analysis of an additional substrate-binding site of glucoamylase $I$. The effect of cyclodextrin on glucoamylase-catalized reactions. Biokbimiya 54, $1725-1731$

Stoffer, B., Frandsen, T. P., Busk, P. K., Schneider, P., Svendsen, I. \& Svensson, B. (1993). Production, purification and characterization of the catalytic domain of glucoamylase from Aspergillus niger. Biothem J 292, 197-202.

Svensson, B., Larsen, K. \& Gunnarson, A. (1986). Characterisation of a glucoamylase G2 from Aspergillus niger. Eur J Biochem 154 497-502

Svensson, B., Jespersen, H., Sierks, M. R. \& MacGregor, E. A.
(1989). Sequence homology between putative raw-starch binding domains from different starch-degrading enzymes. Biochem $J \mathbf{2 6 4}$, 309-311.

Takahashi, T., Kato, K., Ikegami, Y. \& Irie, M. (1985). Different behavior towards raw starch of three forms of glucoamylase from Rbizopus sp. J Biochem 98, 663-671.

Thoma, J. A. \& Koshland, D. E. (1960). Competitive inhibition by substrate during enzyme action. Evidence for the induced-fit theory. J Am Chem Soc 82, 3329-3333.

Ueda, S. \& Saha, B. C. (1983). Behaviour of Endomycopsis fibuligera glucoamylase towards raw starch. Enzyme Microb Tecbnol 5, 196-198.

Vainio, A. E. I., Torkkeli, H. T., Tuusa, T., Aho, S. A., Fagerström, B. R. \& Korhola, M. P. (1993). Cloning and expression of Hormoconis resinae glucoamylase P cDNA in Saccharomyces cerevisiae. Curr Genet 24, 38-44.

van Tilbeurgh, H., Tomme, P., Claeyssens, M., Bhikhabhai, R. \& Petterson, G. (1986). Limited proteolysis of the cellobiohydrolase I from Trichoderma reesei. Separation of functional domains. FEBS Lett 204, 223-227.

Williamson, G., Belshaw, N. J. \& Williamson, M. P. (1992). Oglycosylation in Aspergillus glucoamylase. Conformation and role in binding. Biochem J 282, 423-428.

Received 23 December 1993; revised 23 March 1994; accepted 6 April 1994. 